\title{
IMPLEMENTASI METODE PEMBELAJARAN SMALL GROUP DISCUSSION UNTUK MENINGKATKAN AKTIVITAS BELAJAR PADA KOMPETENSI DASAR JURNAL PENYESUAIAN SISWA KELAS X AKUNTANSI SMK MUHAMMADIYAH KRETEK TAHUN AJARAN 2017/2018
}

\author{
IMPLEMENTATION OF SMALL GROUP DISCUSSION LEARNING METHOD TO \\ INCREASE LEARNING ACTIVITY ON MAIN COMPETENCE OF ADJUSTING \\ ENTRIES STUDENT GRADE X ACCOUNTING SMK MUHAMMADIYAH KRETEK \\ ACADEMIC YEAR 2017/2018
}

Oleh: Niken Fathia Saraswati

Prodi Pendidikan Akuntansi Universitas Negeri Yogyakarta nikenfathia10@gmail.com

Moh. Djazari

Staf Pengajar Jurusan Pendidikan Akuntansi Universitas Negeri Yogyakarta

\begin{abstract}
Abstrak
Penelitian ini dilakukan untuk mengetahui peningkatan Aktivitas Belajar Pada Kompetensi Dasar Jurnal Penyesuaian Siswa Kelas X Akuntansi SMK Muhammadiyah Kretek Tahun Ajaran 2017/2018 melalui Implementasi Metode Pembelajaran Small Group Discussion. Penelitian ini adalah Penelitian Tindakan Kelas (PTK) yang dilaksanakan dalam 2 siklus. Instrumen penelitian yang digunakan yaitu lembar observasi dan catatan lapangan. Teknik analisis data dalam penelitian ini adalah analisis data deskriptif kuantitatif dengan persentase. Hasil penelitian menunjukkan bahwa Implementasi Metode Pembelajaran Small Group Discussion dapat meningkatkan Aktivitas Belajar Pada Kompetensi Dasar Jurnal Penyesuaian Siswa Kelas X Akuntansi SMK Muhammadiyah Kretek Tahun Ajaran 2017/2018. Peningkatan dapat dilihat dari skor persentase observasi Aktivitas Belajar Pada Kompetensi Dasar Jurnal Penyesuaian pada siklus I yaitu 58,80\% menjadi 85,22 \% pada siklus II.
\end{abstract}

Kata kunci: Aktivitas Belajar, Jurnal Penyesuaian, Small Group Discussion

\begin{abstract}
This research aims to know the improvement of Learning Activity by Students Grade X Accounting SMK Muhammadiyah Kretek Academic Year 2017/2018 through the Implementation of Small Group Discussion on the Main Competence of Adjusting Entries. This is an Classroom Action Research that have been conducted in 2 cycles. The research instrument that was used consist of observation form and field note. The data analysis technique that was used in this research called descriptive quantitative analysis shown by percentage. The result of this research shown that the Implementation of Small Group Discussion Learning Method can increase Learning Activity On Main Competence Of Adjusting Entries Student Grade X Accounting SMK Muhammadiyah Kretek academic year $2017 / 2018$ from $58.80 \%$ on cycle I to $85.22 \%$ on cycle II.
\end{abstract}

Keywords: Learning Activity, Adjusting Entries, Small Group Discussion 


\section{PENDAHULUAN}

Aktivitas belajar merupakan kegiatan yang dilakukan oleh siswa, untuk mendapatkan ilmu baru. Siswa yang dahulunya belum mengetahui suatu pengetahuan menjadi tahu termasuk aktivitas belajar. Aktivitas belajar adalah proses yang terjadi pada hampir seluruh proses pembelajaran mulai dari perencanaan hingga pelaporan. Peran siswa di dalam proses pembelajaran haruslah menjadi pembelajar yang aktif. Pembelajar aktif adalah seseorang yang cenderung tertarik pada eksperimentasi aktif dan kurang tertarik pada observasi. Pembelajar aktif yang dimaksudkan adalah pembelajar yang aktif secara fisik maupun mental.

Aktivitas Belajar Pada Kompetensi Dasar Jurnal Penyesuaian merupakan upaya sadar yang dilakukan oleh siswa untuk menggali informasi mengenai Kompetensi Dasar Jurnal Penyesuaian secara mandiri. Aktivitas Belajar Pada Kompetensi Dasar Jurnal Penyesuaian akan bermakna apabila siswa menjadi pembelajar aktif. Seorang siswa disebut pembelajar aktif apabila siswa tersebut mampu menemukan informasi atau ilmu baru secara mandiri. Kemandirian siswa dalam memperoleh informasi Kompetensi Dasar Jurnal Penyesuaian membuat siswa menjadi lebih mahir saat melakukan praktik penyusunan Jurnal Penyesuaian. Siswa yang mampu memahami Kompetensi Dasar Jurnal Penyesuaian secara mandiri tidak akan kebingungan saat menyusun Jurnal Penyesuaian karena siswa tersebut tidak bergantung pada pekerjaan teman yang lain. Hal tersebut berarti bahwa siswa sudah memiliki rasa percaya diri. Selain dapat menyusun Jurnal Penyesuaian secara mandiri, siswa tersebut juga mampu membantu teman lain yang belum mahir.

Setiap siswa tentunya memiliki potensi yang berbeda-beda. Ketika potensi tersebut dapat terfasilitasi dengan baik, tentunya potensi tersebut akan berkembang dengan baik. Salah satu cara untuk mengembangkan potensi siswa, dapat dilakukan dengan cara menggali kemampuan yang dimiliki oleh siswa yaitu kemampuan menguasai mata pelajaran. Ketika setiap siswa berdiskusi tentang suatu hal, maka mereka akan meningkatkan kemampuan berpikir dalam memecahkan suatu masalah dalam diskusi tersebut secara mandiri. Akan tetapi, pada kenyataannya guru masih menjadi pemeran utama dalam kegiatan pembelajaran di kelas. Hal ini menyebabkan siswa menjadi bergantung pada penjelasan guru saja, dan kurang sesuai dengan teori yang seharusnya. Sesuai dengan pendapat Arends (2015: 439) menyatakan bahwa

"the true learning is when students take responsibility for their own learning and not depend solely on a teacher".

Makna dari penjelasan di atas adalah pembelajaran yang tepat adalah pembelajaran di mana siswa memiliki tanggung jawab sendiri atas apa yang mereka pelajari dan tidak bergantung terus menerus kepada guru. Metode pembelajaran yang berpusat kepada guru membuat siswa lebih cepat bosan. Selain itu hasil pembelajaran menjadi kurang bermakna. Berdasarkan pernyataan di atas dapat dikatakan Aktivitas Belajar Pada Kompetensi Dasar Jurnal Penyesuaian akan bermakna apabila pembelajaran terpusat pada siswa. Pembelajaran yang terpusat pada siswa akan meningkatkan rasa ingin tahu terhadap materi yang sedang dipelajari. Munculnya rasa ingin tahu akan memengaruhi kemandirian siswa untuk mencari tahu apa yang ingin diketahui oleh siswa.

Karakteristik Aktivitas Belajar Pada Kompetensi Dasar Jurnal Penyesuaian adalah mengembangkan sikap kritis, analitis, aktif bagi siswa dalam memberikan feedback materi yang diajarkan. Umpan balik atau feedback yang didapatkan berupa pemahaman suatu materi baru. Materi baru 
tersebut kemudian disebarluaskan oleh satu siswa ke siswa yang lain, sehingga terciptalah diskusi dari berbagai informasi yang didapat oleh masing-masing. Diskusi mandiri yang dilakukan oleh siswa, mampu menuntun untuk mencapai tujuan pembelajaran. Tujuan utama pembelajaran adalah membelajarkan siswa, bagaimana cara belajar yang baik, bagaimana membangkitkan siswa untuk belajar dengan segala potensinya untuk memecahkan masalah dalam sepanjang hidupnya. Hal ini sesuai dengan empat pilar pendidikan yang dirumuskan UNESCO, yaitu : learning to know, learning to do, learning to be, learning to live together (Zainal \& Arifin, 2012: 5-6).

Sekolah Menengah Kejuruan (SMK) merupakan salah satu instansi di bidang pendidikan yang menyiapkan agar siswanya siap kerja. Hal yang perlu dilakukan agar menjadi seorang siswa yang siap kerja adalah keaktifan dari pihak siswa itu sendiri. Keaktifan siswa ini harus ditanamkan pada diri siswa sejak mereka menimba ilmu di bangku sekolah. Keaktifan dapat diperoleh dengan cara selalu berpartisipasi di dalam kelas, menanggapi pertanyaan yang diberikan guru maupun teman sebaya, berani menyampaikan ide atau gagasan.

Terdapat dua faktor yang memengaruhi Aktivitas Belajar Pada Kompetensi Dasar Jurnal Penyesuaian, yaitu faktor internal dan eksternal. Faktor internal adalah faktor yang berasal dari siswa sendiri. Faktor internal terdiri dari perhatian, pengamatan, tanggapan, fantasi, ingatan, berpikir, bakat, motif. Faktor eksternal adalah faktor yang berasal dari luar diri siswa. Faktor eksternal terdiri dari kompetensi guru, sarana pendukung, kurikulum, lingkungan, kepemimpinan kelas, biaya.

Metode Pembelajaran Small Group Discussion merupakan suatu proses pembelajaran yang melibatkan 3-5 siswa dalam satu kelompok, yang memiliki tujuan untuk berdiskusi mengenai informasi atau pengetahuan masing-masing anggota kelompok. Metode Pembelajaran Small
Group Discussion mampu memotivasi siswa supaya berani mengungkapkan ide atau pendapat. Ketika setiap siswa berani mengungkapkan pendapatnya, pembelajaran yang terjadi di dalam kelas akan lebih bermakna. Pembelajaran yang bermakna mampu memunculkan setiap potensi yang dimiliki oleh siswa. Potensi siswa selanjutnya dikembangkan agar siswa mampu berinovasi. Menurut Abdul (2013: 200-201) Metode Pembelajaran Small Group Discussion memiliki keunikan dibandingkan dengan metode pembelajaran ceramah dan demonstrasi. Keunikan tersebut ialah pada Metode Pembelajaran Small Group Discussion bahan atau materi pembelajaran ditemukan dan diorganisir oleh siswa sendiri. Dimyati dan Mudjiono (2009: 166) berpendapat bahwa Metode Pembelajaran Small Group Discussion memiliki ciri yang menonjol dibandingkan dengan metode pembelajaran yang lain yaitu:

1) tiap siswa merasa sadar diri sebagai anggota kelompok; 2) tiap siswa merasa memiliki tujuan bersama berupa tujuan kelompok; 3) memiliki rasa membutuhkan dan saling tergantung, 4) ada interaksi dan komunikasi antaranggota; 5) ada tindakan bersama sebagai perwujudan tanggung jawab kelompok.

Melalui Metode Pembelajaran Small Group Discussion, Aktivitas Belajar Pada Kompetensi Dasar Jurnal Penyesuaian diharapkan dapat meningkat. Memulai diskusi dengan dengan kelompok kecil membuat siswa mengungkapkan pendapatnya tanpa merasa takut atau malu. Metode Pembelajaran Small Group Discussion memberikan kesempatan bagi tipe siswa yang pemalu, untuk berlatih mengungkapkan pendapat di dalam diskusi kelompok kecil. Latihan kelompok kecil bisa sangat efektif bagi para pembelajar aktif dan reflektif. Tanpa adanya Metode Pembelajaran Small Group Discussion, siswa cenderung tidak pernah bertanya mengenai materi pembelajaran. Mereka 
hanya menerima materi yang disampaikan guru. Penjelasan ini sesuai dengan pendapat Vrioni (2011: 111) yang mengungkapkan bahwa

"students are rarely asked to procces their learning unless the class also carries a discussion or quiz section".

Maksud dari kutipan tersebut adalah siswa jarang menanyakan tentang materi pembelajaran yang diperolehnya kecuali ketika diadakan diskusi atau kuis di dalam kelas.

Berdasarkan informasi dari guru Mata Pelajaran Akuntansi Kelas X SMK Muhammadiyah Kretek, kompetensi dasar yang sulit bagi siswa adalah Kompetensi Dasar Jurnal Penyesuaian. Guru mengatakan demikian karena Aktivitas Belajar Pada Kompetensi Dasar Jurnal Penyesuaian rendah. Hal ini dibuktikan oleh guru ketika beliau memberikan penjelasan, siswa mengeluh kesulitan. Begitu juga ketika siswa diminta untuk menyusun Jurnal Penyesuaian masih banyak yang salah dalam menjawab. Kesalahan dalam menyusun Jurnal Penyesuaian tetap terjadi setelah guru memberikan penjelasan yang berulang kepada siswa. Oleh karena itu, Aktivitas Belajar Pada Kompetensi Dasar Jurnal Penyesuaian perlu ditingkatkan dengan cara melakukan Implementasi Metode Small Group Discussion.

Berdasarkan hasil observasi awal yang dilakukan oleh peneliti kepada 25 Siswa Kelas X Akuntansi SMK Muhammadiyah Kretek Tahun Ajaran 2017/2018 diperoleh data 14 siswa atau $56 \%$ siswa memerhatikan penjelasan materi yang disampaikan oleh guru. Sejumlah 7 siswa atau $28 \%$ siswa yang sesekali menjawab pertanyaan dari guru secara sukarela tanpa ditunjuk terlebih dahulu. Sejumlah 9 orang siswa atau $36 \%$ siswa bersedia menjawab karena ditunjuk oleh guru. Sejumlah 13 siswa atau $52 \%$ siswa memilih untuk mengerjakan latihan soal secara individu. Sejumlah 11 siswa atau $44 \%$ siswa memiliki semangat untuk memecahkan soal. Skor rata-rata yang diperoleh berdasarkan hasil observasi awal tersebut adalah 43,20 $\%$. Hasil tersebut menunjukkan bahwa skor rata-rata belum mencapai indikator keberhasilan. Pembelajaran di kelas X Akuntansi SMK Muhammadiyah Kretek secara dominan belum terpusat kepada siswa.

Sesuai dengan uraian di atas, peneliti bermaksud akan melakukan penelitian dengan judul "Implementasi Metode Pembelajaran Small Group Discussion untuk Meningkatkan Aktivitas Belajar Pada Kompetensi Dasar Jurnal Penyesuaian Siswa Kelas X Akuntansi SMK Muhammadiyah Kretek Tahun Ajaran 2017/2018”.

\section{METODE PENELITIAN \\ Jenis Penelitian}

Penelitian ini merupakan Penelitian Tindakan Kelas (PTK). Penelitian Tindakan Kelas yaitu penelitian tentang hal-hal yang terjadi di masyarakat atau kelompok sasaran, dan hasilnya langsung dapat dikenakan pada masyarakat yang bersangkutan. (Suharsimi, 2013: 129). Peneliti tidak melakukan penelitian sendiri melainkan berkolaborasi bersama observer. Penelitian Tindakan Kelas terdiri dari beberapa siklus. Setiap siklus terdapat empat langkah yaitu perencanaan, pelaksanaan, pengamatan, dan observasi.

\section{Waktu dan Tempat Penelitian}

Penelitian ini dilaksanakan di SMK Muhammadiyah Kretek yang beralamat di Tegalsari, Donotirto, Kretek, Bantul, Daerah Istimewa Yogyakarta. Penelitian ini dilaksanakan pada bulan Mei 2018.

\section{Subjek dan Objek Penelitian}

Subjek penelitian ini yaitu Siswa Kelas X Akuntansi SMK Muhammadiyah Kretek Tahun Ajaran 2017/2018 yang berjumlah 25 siswa. Objek penelitian ini adalah Aktivitas Belajar Pada Kompetensi Dasar Jurnal 
Penyesuaian melalui Implementasi Metode Pembelajaran Small Group Discussion.

\section{Prosedur Penelitian}

Prosedur Penelitian Tindakan Kelas mengikuti tahap-tahap penelitian yang terdiri dari beberapa siklus. Setiap siklus terdiri dari tahap perencanaan, pelaksanaan, observasi, dan refleksi. Tahap-tahap tersebut dapat diuraikan sebagai berikut :

a. Siklus I

\section{1) Perencanaan}

Pada tahap perencanaan ini rencana tindakan yang dilakukan yaitu peneliti melakukan kesepakatan dengan guru mata pelajaran Akuntansi kelas $\mathrm{X}$ Akuntansi SMK Muhammadiyah Kretek Tahun Ajaran 2017/2018. Kegiatan selanjutnya menyusun Rencana Pelaksanaan Pembelajaran (RPP), membentuk kelompok, dan menyusun materi.

2) Pelaksanaan Tindakan

Pada tahap ini, guru melaksanakan kegiatan pembelajaran sebagaimana telah direncanakan sebelumnya, yaitu pembelajaran menggunakan Metode Small Group Discussion. Pelaksanaan bersifat fleksibel dan terbuka terhadap perubahan-perubahan yang terjadi selama proses pembelajaran berlangsung.

3) Observasi

Observasi dilakukan oleh peneliti bersama rekan observer di mana peneliti menjadi pengamat utama. Observasi dilakukan selama proses pembelajaran, menggunakan Metode Pembelajaran Small Group Discussion. Observasi ini berlangsung menggunakan lembar observasi dan catatan lapangan.

4) Refleksi

Berdasarkan hasil pengamatan yang dilakukan pada seluruh kegiatan siklus I selanjutnya dilakukan analisis, pemaknaan, penjelasan dan penyimpulan data. Hasil kesimpulan yang didapat berupa Aktivitas Belajar Pada Kompetensi Dasar Jurnal Penyesuaian, daftar permasalahan dan kendala-kendala yang dihadapi di lapangan selama melaksanakan proses pembelajaran dengan menerapkan Metode Pembelajaran Small Group Discussion. Hasil ini kemudian dijadikan dasar untuk melakukan perencanaan pada siklus II.

b. Siklus II

Siklus II ini disusun setelah siklus I terlaksana. Pada siklus II kegiatannya hampir ssama dengan siklus I, akan tetapi tindakan pada siklus II mengacu pada hasil refleksi siklus I. Siklus II bertujuan untuk memperbaiki pelaksanaan pembelajaran pada siklus I.

\section{Teknik Pengumpulan Data}

Teknik pengumpulan data yang digunakan dalam penelitian ini, yaitu:

a. Observasi

Observasi merupakan pengamatan dengan menggunakan penglihatan, penciuman, pendengaran, perabaan, atau kalau perlu dengan pengecapan (Trianto, 2011: 267). Sebelum melaksanakan observasi perlu menyusun kisi-kisi berupa indikator yang akan diobservasi. Hal yang diobservasi meliputi kegiatan siswa saat pembelajaran berlangsung. Observasi pada penelitian ini dilakukan untuk mengamati segala aktivitas saat proses pembelajaran Jurnal Penyesuaian berlangsung dengan Implementasi Metode Pembelajaran Small Group Discussion.

b. Dokumentasi

Dokumentasi merupakan teknik pengumpulan data dengan menyelidiki benda-benda tertulis seperti buku, majalah, dokumen, peraturan-peraturan, notulen rapat, catatan harian, dan sebagainya (Suharsimi, 2013:201). 


\section{Instrumen Penelitian}

Instrumen penelitian yang digunakan dalam penelitian ini adalah:

a. Lembar Observasi

Lembar observasi digunakan sebagai pedoman untuk melakukan pengamatan ditujukan untuk mendapatkan data yang ingin diketahui oleh peneliti.

b. Dokumentasi

Dokumentasi adalah upaya untuk memberikan gambaran bagaimana sebuah Penelitian Tindakan Kelas dilakukan. Dokumentasi yang digunakan berupa dokumentasi nontes yang terdiri dari silabus, Rencana Program Pembelajaran (RPP) Jurnal Penyesuaian, catatan lapangan, daftar nama Siswa Kelas X Akuntansi, dan foto saat kegiatan pembelajaran berlangsung.

\section{Teknik Analisis Data}

a. Analisis Data Deskriptif Kuantitatif

Analisis yang digunakan pada penelitian ini adalah Analisis Data Deskriptif Kuantitatif. Untuk menganalisis data secara kuantitatif, langkah-langkah yang digunakan adalah sebagai berikut:

1) Menentukan kriteria pemberian skor terhadap masing-masing indikator pada setiap aspek Aktivitas Belajar Pada Kompetensi Dasar Jurnal Penyesuaian yang diamati.

2) Menghitung dan menjumlahkan skor Aktivitas Belajar Pada Kompetensi Dasar Jurnal Penyesuaian pada setiap indikator.

3) Menghitung persentase skor Aktivitas Belajar Pada Kompetensi Dasar Jurnal Penyesuaian pada setiap indikator yang diamati dengan rumus:

Skor Aktivitas

Belajar

Pada Jurnal

Penyesuaian $=\frac{\text { Skor total tiap indikator }}{\text { Skor maksimal }} \times 100 \%$
4) Menghitung persentase skor ratarata Aktivitas Belajar Pada Kompetensi Dasar Jurnal Penyesuaian yang diamati dengan rumus:

$\begin{aligned} & \text { Skor rata- } \\ & \text { rata } \\ & \text { Aktivitas }\end{aligned}$
$\begin{aligned} & \text { Belajar } \\ & \text { Pada Jurnal }\end{aligned}$
$\begin{aligned} & \text { Senyesuaian } \\ & \text { Jumlah skor maksimal }\end{aligned}$
indikator

5) Menyajikan data dalam bentuk tabel atau grafis sehingga data mudah dipahami

6) Menarik kesimpulan

Penarikan kesimpulan dilakukan setelah data disajikan dalam bentuk pernyataan. Penarikan kesimpulan ini bertujuan untuk menjawab masalah yang diajukan diawal penelitian.

b. Penyajian Data

Penyajian data ini dapat dilakukan dalam bentuk tabel, grafik, dan sebagainya (Sugiyono, 2013: 341). Penyajian data dilakukan dalam rangka penyusunan informasi secara sistematis mulai dari perencanaan, pelaksanaan tindakan dan refleksi pada masingmasing siklus.

c. Penarikan Kesimpulan

Penarikan kesimpulan merupakan upaya pencarian makna data. Penarikan kesimpulan dilakukan untuk menjawab rumusan masalah yang diajukan pada awal penelitian.

\section{HASIL PENELITIAN DAN PEMBAHASAN \\ Observasi Awal}

Sebelum melaksanakan penelitian, peneliti mempersiapkan segala hal yang dibutuhkan untuk kelancaran penelitian mulai dari mengurus surat ijin penelitian hingga ke hal-hal teknis yang diuraikan berikut. Peneliti berdiskusi dengan guru 
kelas terlebih dahulu, menentukkan materi dan jumlah jam saat tindakan. Selain itu peneliti tentunya menyusun Rencana Pelaksanaan Pembelajaran (RPP) disesuaikan dengan Rencana Pelaksanaan Pembelajaran (RPP) yang dibutuhkan di kelas X Akuntansi SMK Muhammadiyah Kretek. Persiapan yang diperlukan lainnya adalah membuat papan nomor sederhana yang akan dipakai setiap peserta didik saat proses tindakan. Hal ini bertujuan agar peneliti lebih mudah saat memberikan skor.

Persiapan lain yang dilaksanakan adalah membagi siswa menjadi 5 kelompok. Masing-masing kelompok terdiri dari 5 siswa. Pembagian kelompok dilakukan secara acak. Mencari hadiah atau reward untuk siswa yang belajar aktif saat proses tindakan berlangsung merupakan hal yang dilakukan sebelum tindakan.

\section{Laporan Siklus I}

Pelaksanaan Pembelajaran Jurnal Penyesuaian dengan penerapan Metode Pembelajaran pada siklus I dilaksanakan pada hari Rabu, 9 Mei 2018 pukul 07.00 WIB hingga 09.15 WIB atau pada jam pertama dan kedua selama 2 jam pelajaran. Satu jam pelajaran terdiri dari 45 menit. Guru menginformasikan tujuan pembelajaran, serta cara penilaian yang akan dilakukan terkait dengan kompetensi yang dipelajari. Tujuan dari pembelajaran pada siklus I adalah siswa mampu menyusun jurnal penyesuaian berdasarkan neraca saldo dan data penyesuaian yang diberikan. Hasil pengamatan menunjukkan bahwa Skor ratarata siklus I belum memenuhi kriteria minimal yang ditentukan yaitu sebesar $75 \%$. Skor ratarata seluruh indikator yang diperoleh pada siklus I sebesar $58,80 \%$.

\section{Laporan Siklus II}

Pelaksanaan penelitian tindakan kelas siklus II dilakukan pada hari Jumat, 11 Mei 2018 pukul 10.30 WIB hingga 12.00 WIB atau pada jam kelima dan keenam 2 jam pelajaran. Hasil pengamatan diperoleh skor rata-rata Aktivitas Belajar Pada Kompetensi Dasar Jurnal Penyesuaian Siklus II adalah sebesar
$85,22 \%$. Hasil tersebut menunjukkan telah tercapainya indikator keberhasilan penelitian yaitu persentase rata-rata Aktivitas Belajar Pada Kompetensi Dasar Jurnal Penyesuaian $\geq 75 \%$.

Berikut ini data peningkatan Aktivitas Belajar Pada Kompetensi Dasar Jurnal Penyesuaian Siswa Kelas X Akuntansi SMK Muhammadiyah Kretek Tahun Ajaran 2017/2018

Tabel 1. Peningkatan Aktivitas Belajar Pada Kompetensi Dasar Jurnal Penyesuaian

\begin{tabular}{|c|c|c|c|}
\hline \multirow[b]{2}{*}{ No } & \multirow[b]{2}{*}{ Indikator } & \multicolumn{2}{|c|}{ Peningkatan } \\
\hline & & $\begin{array}{c}\text { Siklus } \\
\text { I }\end{array}$ & $\begin{array}{c}\text { Siklus } \\
\text { II }\end{array}$ \\
\hline 1 & $\begin{array}{l}\text { Siswa } \\
\text { memerhatikan } \\
\text { penjelasan guru } \\
\text { saat menyampaikan } \\
\text { pembelajaran }\end{array}$ & $58 \%$ & $\begin{array}{c}86,95 \\
\%\end{array}$ \\
\hline 2 & $\begin{array}{l}\text { Siswa membaca } \\
\text { materi mengenai } \\
\text { Jurnal Penyesuaian }\end{array}$ & $50 \%$ & $\begin{array}{c}76,08 \\
\%\end{array}$ \\
\hline 3 & $\begin{array}{l}\text { Siswa } \\
\text { menyampaikan } \\
\text { pertanyaan kepada } \\
\text { guru saat } \\
\text { menjelaskan materi } \\
\text { Jurnal Penyesuaian }\end{array}$ & $54 \%$ & $\begin{array}{c}84,78 \\
\%\end{array}$ \\
\hline 4 & $\begin{array}{l}\text { Siswa aktif } \\
\text { membantu } \\
\text { kelompok } \\
\text { menyelesaikan } \\
\text { tugas }\end{array}$ & $66 \%$ & $\begin{array}{c}89,13 \\
\%\end{array}$ \\
\hline 5 & $\begin{array}{l}\text { Siswa bersemangat } \\
\text { dalam diskusi } \\
\text { kelompok }\end{array}$ & $66 \%$ & $\begin{array}{c}89,13 \\
\%\end{array}$ \\
\hline Per & $\begin{array}{l}\text { entase skor rata-rata } \\
\text { seluruh indikator }\end{array}$ & $\begin{array}{c}58,80 \\
\%\end{array}$ & $\begin{array}{c}85,22 \\
\%\end{array}$ \\
\hline
\end{tabular}

Berdasarkan pada hasil pengamatan yang diperoleh aktivitas belajar terus meningkat dari siklus I ke siklus II. Persentase skor rata-rata pada indikator siswa memerhatikan penjelasan guru saat menyampaikan pembelajaran meningkat 
dari $58 \%$ menjadi $86,95 \%$. Siswa membaca materi mengenai Jurnal Penyesuaian meningkat dari $50 \%$ menjadi $76,08 \%$. Siswa menyampaikan pertanyaan kepada guru saat menjelaskan materi Jurnal Penyesuaian meningkat dari $54 \%$ menjadi $84,78 \%$. Siswa aktif membantu kelompok menyelesaikan tugas meningkat dari $66 \%$ menjadi $89,13 \%$. Siswa bersemangat dalam diskusi kelompok meningkat dari $66 \%$ menjadi $89,13 \%$.

Pada siklus I Aktivitas Belajar Pada Kompetensi Dasar Jurnal Penyesuaian masih rendah. Peningkatan terjadi pada siklus II. Siswa yang awalnya hanya berdiam diri saat anggota kelompok lain berdiskusi, pada siklus II siswa sudah aktif untuk memberikan saran, masukan, dan jawaban. Hal tersebut sesuai dengan teori yang diungkapkan oleh Rudi (2013: 148) yaitu siswa yang aktif berupaya untuk membangun pengetahuannya sendiri. Hasil penelitian ini relevan dengan penelitian yang dilakukan oleh Evina (2014) yang berjudul "Penerapan Model Pembelajaran Small Group Discussion dengan Strategi Information Search untuk Meningkatkan Aktivitas dan Hasil Belajar Akuntansi Siswa Kelas X AK di SMK Swasta Bukit Cahaya Sidikalang Tahun Ajaran 2013/2014". Pada penelitian yang dilakukan oleh Evina dapat diperoleh hasil adanya peningkatan aktivitas belajar setelah diterapkan Metode Pembelajaran Small Group Discussion. Pada siklus I, persentase aktivitas belajar siswa adalah $40 \%$ meningkat menjadi $88,57 \%$ di siklus II. penelitian ini juga relevan dengan penelitian yang dilakukan oleh Budi Mangaratua Silaen (2013) yang berjudul "Penerapan Model Pembelajaran Small Group Discussion Dengan Metode Group Investigation untuk Meningkatkan Aktivitas dan Hasil Belajar Akuntansi Siswa di Kelas X IS SMA Swasta Budisatrya Medan Tahun Pembelajaran 2012/2013”. Hasil dari penelitian tersebut adalah terjadinya peningkatan aktivitas belajar siswa dari siklus I sebesar 13,2 \% menjadi $73,68 \%$ pada siklus II.
Hal ini dapat disimpulkan bahwa, Implementasi Metode Pembelajaran Small Group Discussion dapat meningkatkan Aktivitas Belajar Pada Kompetensi Dasar Jurnal Penyesuaian Siswa Kelas X Akuntansi SMK Muhammadiyah Kretek Tahun Ajaran 2017/2018. Metode Pembelajaran Small Group Discussion mampu menarik perhatian siswa sehingga dapat meningkatkan Aktivitas Belajar Pada Kompetensi Dasar Jurnal Penyesuaian Siswa Kelas X Akuntansi SMK Muhammadiyah Kretek Tahun Ajaran 2017/2018.

\section{SIMPULAN DAN SARAN Simpulan}

Berdasarkan hasil penelitian dan pembahasan maka dapat ditarik kesimpulan bahwa, Implementasi Metode Pembelajaran Small Group Discussion telah berhasil meningkatkan Aktivitas Belajar Pada Kompetensi Dasar Jurnal Penyesuaian Siswa Kelas X Akuntansi SMK Muhammadiyah Kretek Tahun Ajaran 2017/2018. Peningkatan Aktivitas Belajar Pada Kompetensi Dasar Jurnal Penyesuaian Siswa Kelas X Akuntansi SMK Muhammadiyah Kretek Tahun Ajaran 2017/2018 dibuktikan dari hasil penelitian yang menunjukkan skor rata-rata 58,80\% pada siklus I meningkat ke $85,22 \%$ pada siklus II. Hal ini berarti bahwa hasil penelitian sudah mencapai indikator keberhasilan yaitu sebesar $\geq 75 \%$ siswa aktif.

\section{Saran}

Berdasarkan hasil penelitian terhadap Aktivitas Belajar Pada Kompetensi Dasar Jurnal Penyesuaian, aktivitas membaca materi Jurnal Penyesuaian memiliki skor terendah. Guru diharapkan dapat menyusun strategi yang baik agar siswa terbiasa untuk membaca materi Jurnal Penyesuaian. Salah satu cara yang dapat diterapkan adalah guru memberikan kesempatan kepada siswa untuk membaca materi di awal pembelajaran 5-10 menit. 


\section{DAFTAR PUSTAKA}

Abdul Majid. (2013). Strategi Pembelajaran. Bandung: Remaja Rosdakarya.

Arends, Richard. (2015). Learning To Teach. New York: McGraw Hill Education.

Budi Mangaratua Silaen. (2013). Penerapan Model Pembelajaran Small Group Discussion Dengan Metode Group Investigation untuk Meningkatkan Aktivitas dan Hasil Belajar Akuntansi Siswa di Kelas X IS SMA Swasta Budisatrya Medan Tahun Pembelajaran 2012/2013. Skripsi. Medan : Universitas Negeri Medan.

Dimyati \& Mudjiono. (2009). Belajar dan Pembelajaran. Jakarta: Rineka Cipta.

Evina. (2014). Penerapan Model Pembelajaran Small Group Discussion dengan Strategi Information Search untuk Meningkatkan Aktivitas dan Hasil Belajar Akuntansi Siswa Kelas X AK di SMK Swasta Bukit Cahaya Sidikalang Tahun Ajaran 2013/2014. Skripsi. Medan : Universitas Negeri Medan.

Rudi Hartono. (2013). Ragam Model Mengajar yang Mudah Diterima Murid. Yogyakarta: Diva Press.

Sugiyono. (2013). Metode Penelitian Pendidikan (Pendekatan Kualitatif, Kuantitatif, dan $R \& D)$. Bandung: Alfabeta.

Suharsimi Arikunto. (2013). Prosedur Penelitian: Suatu Pendekatan Praktik. Jakarta: Rineka Cipta.

Trianto. (2011). Pengantar Penelitian Pendidikan bagi Pengembangan Profesi Pendidikan dan Tenaga Kependidikan. Jakarta: Kencana.
Vrioni, R. (2011). Effect of Group Learning on the Academic Performance of University Students, 33, 111-117.

Zainal, A \& Arifin, S. (2012). Pengembangan Pembelajaran Aktif dengan ICT. Yogyakarta: Skripta. 